\title{
Documenting, disseminating and archiving data from the Teotihuacan Mapping Project
}

\author{
Angela C. Huster ${ }^{1, *}$, Oralia Cabrera-Cortés ${ }^{1}$, Marion Forest ${ }^{1}$, \\ Francis P. McManamon ${ }^{2}$, Ian G. Robertson ${ }^{3} \&$ Michael E. Smith $^{1}$
}

The Teotihuacan Mapping Project (TMP) provided vast quantities of invaluable data to our understanding of this famous ancient city. The 'Documenting, Disseminating, and Archiving Data from the Teotihuacan Mapping Project' aims to analyse, re-examine and ultimately coalesce TMP data for entry into The Digital Archaeological Record.

The Teotihuacan Mapping Project (TMP) was a major archaeological project of the twentieth century. In addition to the endlessly reprinted map of the ancient city of Teotihuacan, Mexico (Figure 1; see Millon 1973; Millon \& Altschul 2015), the project and its associated artefact collections have supported ongoing research on a wide range of archaeological topics. The future of the project's data, however, must be assured. Over the next two years, the current project, 'Documenting, Disseminating, and Archiving Data from the Teotihuacan Mapping Project' (National Science Foundation grant 1723322), will carry out key analyses, standardise datasets and make project data publicly available through the Digital Archaeological Record (tDAR) (McManamon et al. 2017).

\section{The TMP}

The impact of the city and state of Teotihuacan (c. 100 BC-600 AD), located approximately 30 miles north-east of Mexico City, was felt across much of Mesoamerica through a combination of direct rule in some localities, and cultural influence in others. In the 1960s, the TMP conducted a near-full coverage survey of the city, mapping over 5000 individual structures and collecting surface artefacts from almost all of them. The project also conducted test excavations, with the aim of refining chronological questions and testing the accuracy of the survey data. The project established the size of the city $(2000+\mathrm{ha})$, its dense urban character, systematic layout and approximate population (80-120k) (Cowgill 2015a). For their achievements with the project, René Millon and George Cowgill were

1 School of Human Evolution and Social Change, Arizona State University, P.O. Box 872402, Tempe, AZ 852872402, USA

2 Center for Digital Antiquity, School of Human Evolution and Social Change, Arizona State University, P.O. Box 872404, Tempe, AZ 85287-2402, USA

3 Independent Researcher, 41183 Circle 5 Estates, Calgary T3Z 2T4, Canada

* Author for correspondence (Email: ahuster@asu.edu)

(C) Antiquity Publications Ltd, 2018

ANTIQUITY 92 363, e9 (2018): 1-6

https://doi.org/10.15184/aqy.2018.102 


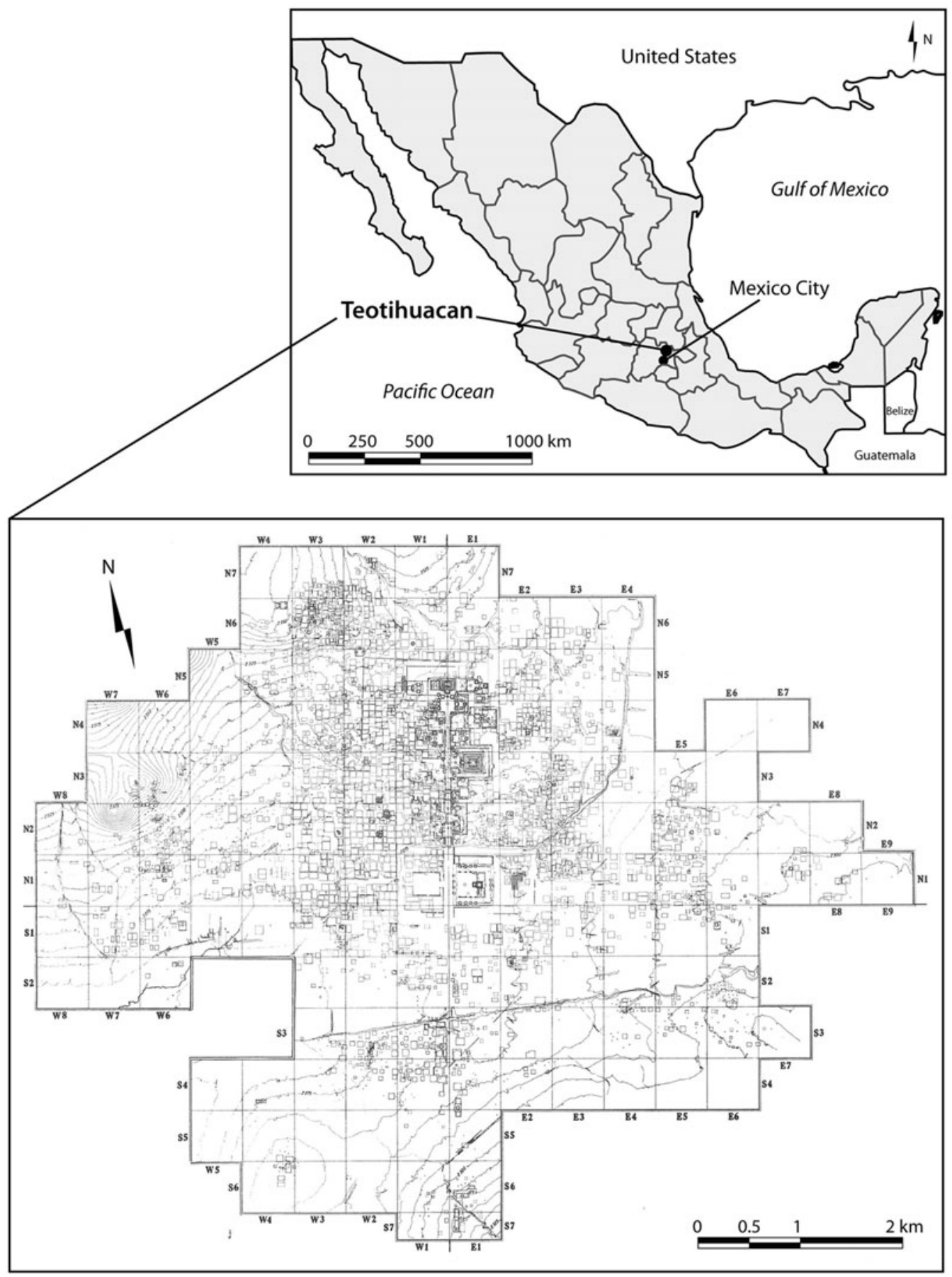

Figure 1. The Teotihuacan Mapping Project map of the ancient city (based on Millon 1973)

(C) Antiquity Publications Ltd, 2018 


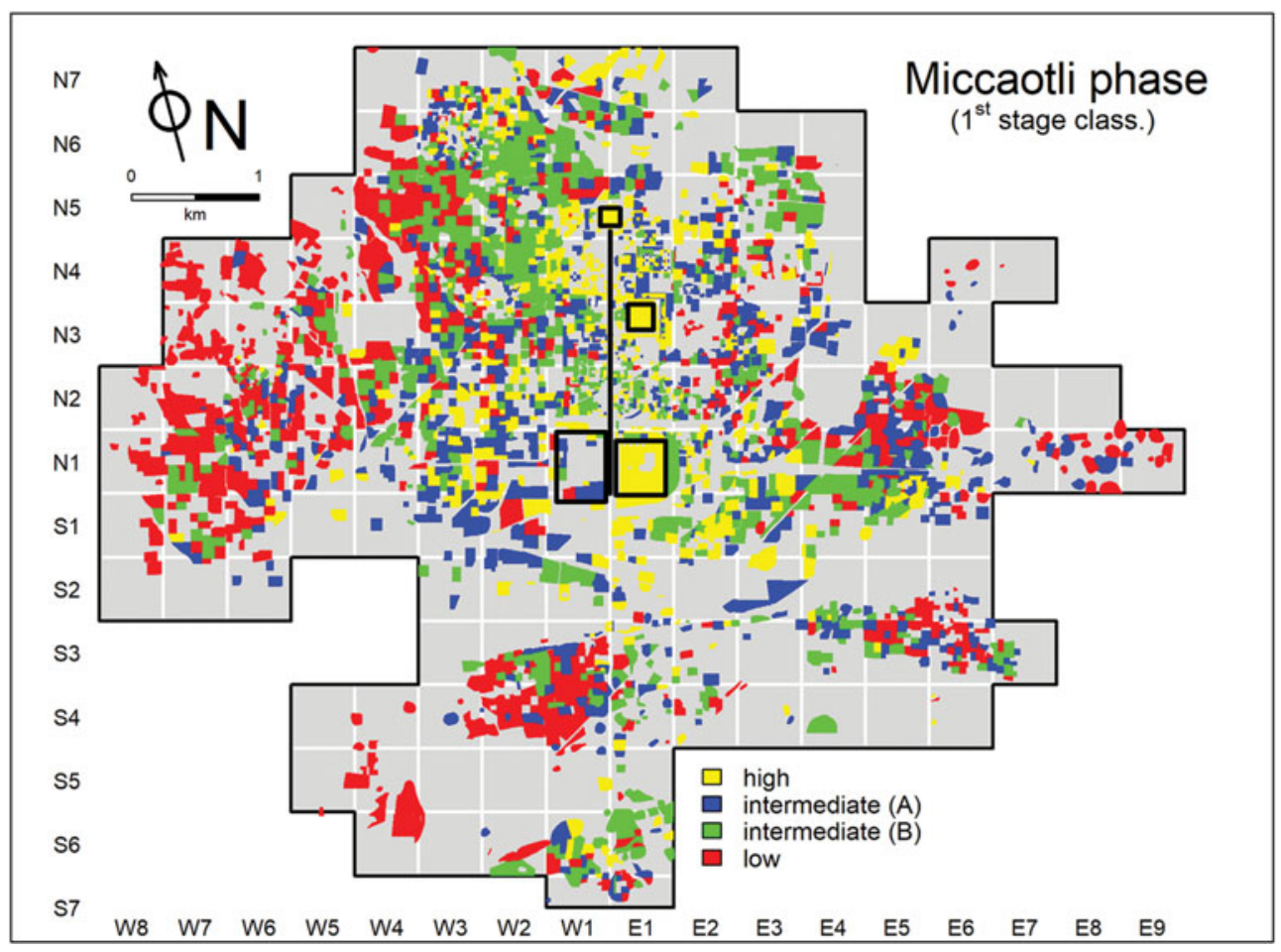

Figure 2. Recent work on the distribution offour wealth/status classes, as inferred from Teotihuacan Mapping Project ceramic data for the Miccaotli phase occupation (adapted from Robertson 2015: fig. 4).

given the highest honour in New World archaeology, the Alfred V. Kidder Award from the American Anthropological Association (in 2004).

The data produced by the project-particularly the artefact collections and associated digital records - have been central to studies of the ancient city (Cowgill 2015b; Robertson 2015). Surface data were the basis for many key discoveries, such as the identification of two neighbourhoods bearing distinct ethnic identities, and of a large district devoted to ceramic production - all of which were verified by excavation. In subsequent years, studies have used TMP data to reveal much about the internal economic and social organisation of Teotihuacan, including the nature of spatio-temporal variation in wealth and status (see Robertson 2015) (Figure 2). Despite its many successes, however, analysis and publication of TMP survey and test excavation material have been hindered by the sheer scope of the project. A few artefact types still lack basic tabulations, and others have been tabulated but the resulting data not fully analysed. For example, our understanding of the scale of obsidian production in the city, which was briefly debated and then largely dropped (see Clark 1986; Spence 1987), can be improved with new studies on existing collections.

\section{The current project}

The current project has five goals for the TMP data: 1) completion of the study of crucial artefacts, including those used to infer craft production, exchange and other economic 


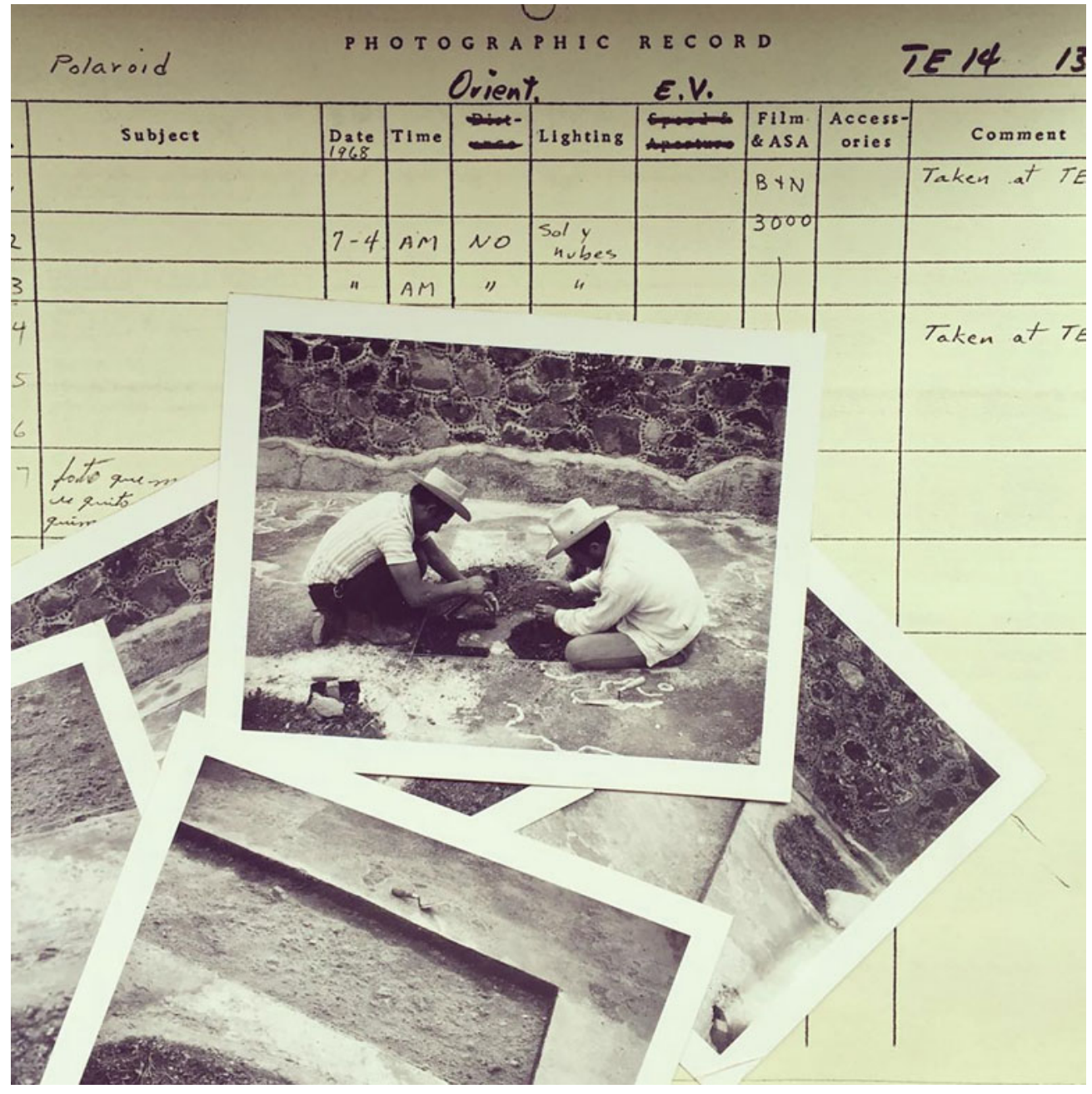

Figure 3. Historic photograph catalogue and photographs from the Teotihuacan Mapping Project test excavations in 1964. activities; 2) write-up of the TMP test excavations; 3) cleaning, organising and scanning project notes and data files (Figure 3); 4) creation of new GIS shapefiles of the TMP architectural map to supplement extant

tDRR

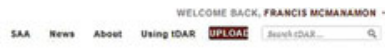

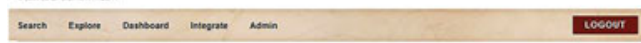

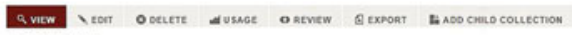

The Teotihuacan Mapping Project (TMP)

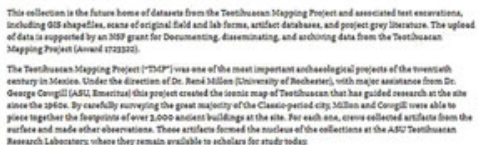

Figure 4. The tDAR Collection website page for the project.

(C) Antiquity Publications Ltd, 2018 files; and 5) depositing the digital files, along with robust descriptive and technical metadata, in a collection (Figure 4) in tDAR, where they can be accessed easily and widely and used for future education, public outreach, research and scholarship. 


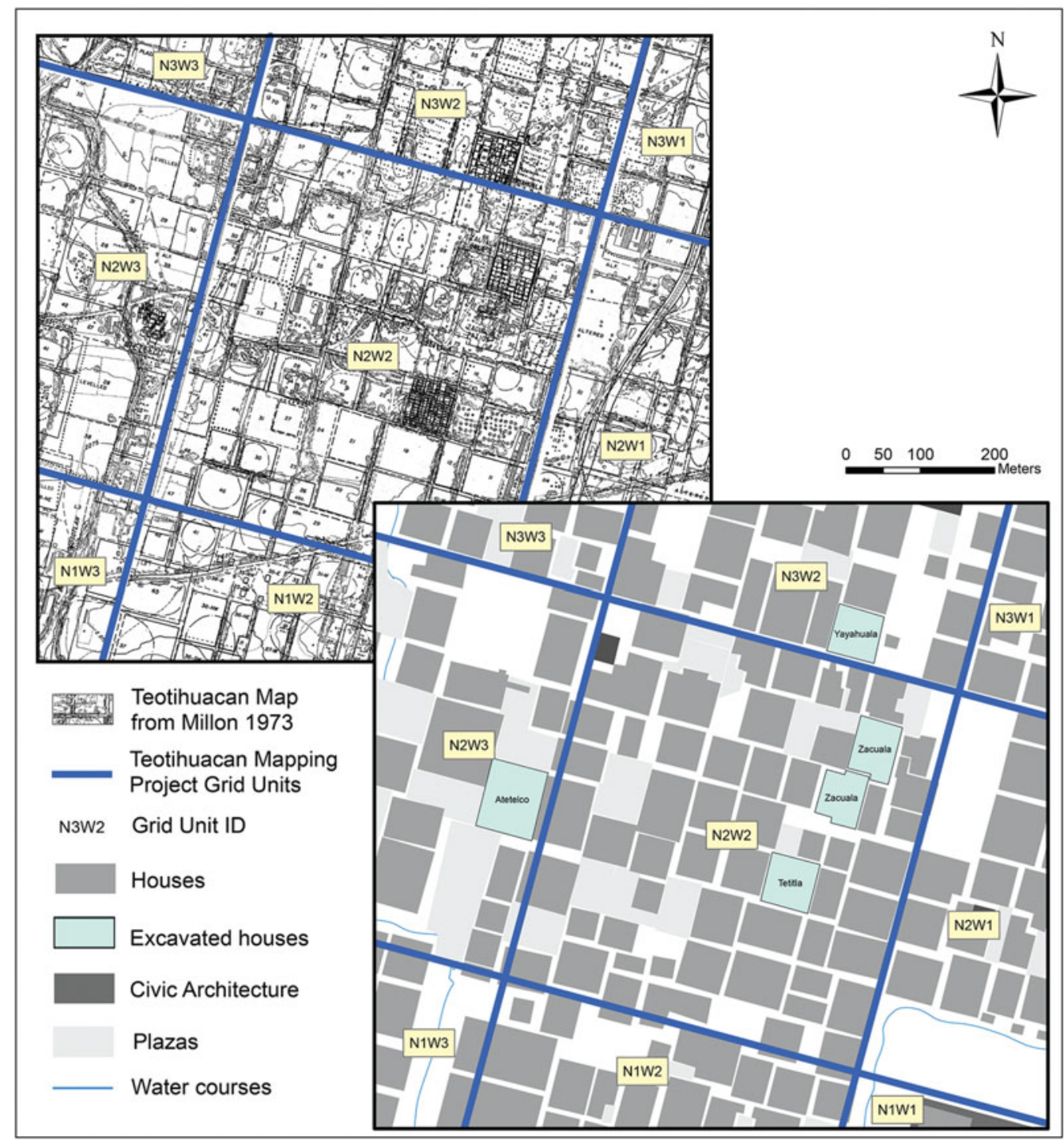

Figure 5. Original Teotihuacan Mapping Project (TMP) detail and current GIS digitisation of the TMP architectural map.

\section{A brief sample of current work}

A brief presentation of recent research illustrates the continuing potential of the TMP data. Robertson and Cabrera-Cortés (2017) analysed the spatial distributions of artefact types potentially associated with maguey sap production. They demonstrated the utility of even the better-studied ceramic collections for answering new questions. A pilot version of the architectural GIS for the city provided comparative data on service provisioning at the site (Dennehy et al. 2016), showing the continuing value of the purely spatial data generated by the project. The complete version of the TMP GIS is

(C) Antiquity Publications Ltd, 2018 
currently under construction (Figure 5). Smith and Paz Bautista (2015) completed the first analysis of the almena (roof decoration) fragments collected by the TMP; other

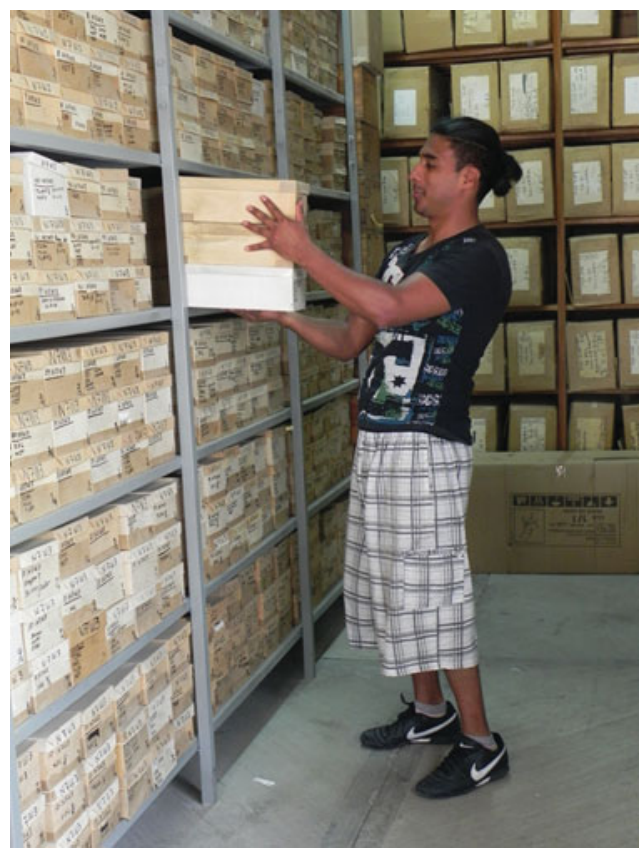

Figure 6. Current artefact storage at the ASU Teotihuacan Research Laboratory.

\section{References}

Clark, J.E. 1986. From mountains to molehills: a critical review of Teotihuacan's obsidian industry. Research in Economic Anthropology, Supplement 2: 23-74.

Cowgill, G.L. 2015a. Ancient Teotihuacan. Cambridge: Cambridge University Press. https://doi.org/10.1017/CBO9781139046817

- 2015b. The Teotihuacan Mapping Project: experiences with data files, big questions, and some research priorities for Teotihuacan. Ancient Mesoamerica 26: 153-61. https://doi.org/10.1017/CBO9781139046817

Dennehy, T.J., B.W. Stanley \& M.E. Smith. 2016. Social inequality and access to services in premodern cities. Archeological Papers of the American Anthropological Association 27: 143-60. https://doi.org/10.1111/apaa.12079

McManamon, F.P., K.W. Kintigh, L.A. Ellison \& A. BRIN. 2017. tDAR: a cultural heritage archive for twenty-first-century public outreach, research, and resource management. Advances in Archaeological Practice 5: 238-49. https://doi.org/10.1017/aap.2017.18 artefact categories will benefit from similar renewed attention. The project collections are housed at the Arizona State University Teotihuacan Research Laboratory (https://shesc.asu.edu/centers/ teotihuacan-research-laboratory) in San Juan Teotihuacan (Figure 6), and further research is encouraged.

Millon, R. 1973. Urbanization at Teotihuacán, Mexico: the Teotihuacan map. Austin: University of Texas Press.

Millon, R. \& J.H. Altschul. 2015. The making of the map: the origin and lessons of the Teotihuacan Mapping Project. Ancient Mesoamerica 26: 135-51. https://doi.org/10.1017/S0956536115000073

RoberTson, I.G. 2015. Investigating Teotihuacan through TMP surface collections and observations. Ancient Mesoamerica 26: 163-81. https://doi.org/10.1017/S0956536115000115

Robertson, I.G. \& M.O. Cabrera-Cortés. 2017. Teotihuacan pottery as evidence for subsistence practices involving maguey sap. Archaeological and Anthropological Sciences 9: 11-27. https://doi.org/10.1007/s12520-016-0415-z

Smith, M.E. \& C. Paz Bautista. 2015. Las almenas en la ciudad antigua de Teotihuacan. Mexicon 37(5): 118-25.

SPENCE, M.W. 1987. The scale and structure of obsidian production in Teotihuacan, in E.M. de Tapia \& E.C. Rattray (ed.) Teotihuacan: nuevos datos, nuevas sintesis, nuevos problemas: 429-50. Mexico City: Instituto of Anthropological Research, National Autonomous University of Mexico.

(C) Antiquity Publications Ltd, 2018 